\title{
Effect of tree species identity and related habitat parameters on understorey bryophytes - interrelationships between bryophyte, soil and tree factors in a 50-year-old experimental forest
}

\author{
Kaja Rola (D) Vítězslav Plášek (D). \\ Katarzyna Rożek $\mathbb{D} \cdot$ Szymon Zubek
}

Received: 3 February 2021 / Accepted: 29 June 2021 / Published online: 16 July 2021

(C) The Author(s) 2021

\begin{abstract}
Aim Overstorey tree species influence both soil properties and microclimate conditions in the forest floor, which in turn can induce changes in ground bryophyte communities. The aim of the study was to investigate the effect of tree species identity and the most important habitat factors influencing understorey bryophytes.

Methods We assessed the effect of 14 tree species and related habitat parameters, including soil parameters, vascular plant presence and light intensity on bryophytes in monospecific plots covered by nearly fifty-year-old trees in the Siemianice Experimental Forest (Poland).

Results The canopy tree species determined bryophyte species richness and cover. The strongest differences were observed between plots with deciduous and coniferous trees. Soils with a more acidic $\mathrm{pH}$ and lower content of macronutrients supported larger bryophyte coverage. We also found a positive
\end{abstract}

Responsible Editor: Stavros D. Veresoglou.

K. Rola $(\bowtie) \cdot$ K. Rożek $\cdot$ S. Zubek

Institute of Botany, Faculty of Biology, Jagiellonian

University, Gronostajowa 3, 30-387 Kraków, Poland

e-mail:kaja.skubala@uj.edu.pl

V. Plášek

Department of Biology and Ecology, Faculty of Science, University of Ostrava, Chittussiho 10, 71000 Ostrava, Czech Republic correlations between vascular plants and availability of light as well as bryophyte species richness.

Conclusion Tree species identity and differences in habitat conditions in the forest floor lead to changes of ground bryophyte richness, cover and species composition. Consequently, the changes in the dominant tree species in the stand may result in significant repercussions on ground bryophyte communities. We indicated that the introduction of alien tree species, i.e. Quercus rubra, has an adverse effect on bryophyte communities and suggested that the selection of tree species that contribute to the community consistent with the potential natural vegetation is highly beneficial for maintaining ground bryophyte biodiversity.

Keywords Bryophytes - Deciduous and coniferous tree species · Forest floor - Native and alien tree species $\cdot$ Species richness $\cdot$ Soil parameters

\section{Introduction}

Ground bryophytes constitute an integral part of forest ecosystems. They play an important role as a crucial component of forest diversity (Kriebitzsch et al. 2013; Longton 1992), contributing to carbon and nutrient cycling, water balance and erosion control (Oechel and Van Cleve 1986; Turetsky 2003). These organisms are strongly dependent on various abiotic and biotic conditions (Proctor 2008). The abiotic factors include primarily substrate availability (e.g. Müller et al. 2019), 
composition and quantity of litter (e.g. Startsev et al. 2008; Weibull and Rydin 2005), soil fertility (e.g. Jagodziński et al. 2018), soil acidity (e.g. Tilk et al. 2018), light availability (e.g. Márialigeti et al. 2016; Tinya et al. 2009) and soil moisture (e.g. Mills and MacDonald 2005). Bryophytes are also dependent on composition and coverage of associated vascular plant communities (Löbel et al. 2006; Márialigeti et al. 2009; Yan et al. 2013).

It would be hard not to mention the main plant components of the forest, which are trees. Trees constitute the majority of biomass in forest complexes and are responsible for the functioning of the forest interior (Ellison et al. 2005). They are particularly important for soil-forming processes since leaf litter and root decomposition are the most important source of soil organic matter (Augusto et al. 2003). Tree species composition has been proven to shape the chemical properties of litter and thereby could strongly influence bryophyte communities indirectly via alternation of microclimatic conditions in a forest stand (e.g. Arno et al. 2012).

Several studies have been conducted to elucidate bryophyte distribution and richness in forests to give insight into the different factors that influence their growth (e.g. Gosselin et al. 2017; Jansová and Soldan 2006; Király and Ódor 2010; Vellak and Ingerpuu 2005). Most of the studies concern epiphytic bryophytes, and thus the effect of tree species on bryophyte diversity and composition is relatively well recognised. The main factors are related to tree age, inclination of the trunk or branches, bark structure, bark $\mathrm{pH}$ and water capacity (e.g. Fritz et al. 2009; Király and Ódor 2010). On the other hand, little is known about the tree effect on ground bryophytes. Moreover, most of the previous studies were conducted in natural old-growth or mature managed forests that comprised a mixed composition of tree species, which certainly makes it difficult to estimate the direct effect of tree species on bryophytes. As regards ground bryophytes, Jagodziński et al. (2018) studied the effect of tree species on bryophytes in the disturbed ecosystem of a reclaimed lignite mine spoil heap and concluded that the main factors affecting bryophyte diversity are light availability, soil $\mathrm{pH}$ and $\mathrm{C} / \mathrm{N}$ ratio. Another factor was reported by Weibull and Rydin (2005) who found that the amount of litter influenced species richness of bryophytes growing on granite boulders in mixed forests. Márialigeti et al. (2009) recognised substrate availability, litter cover, stand age, and stand structural diversity as the factors influencing the development of a bryophyte layer in temperate-mixed forests; however, soil properties were not investigated in this study. Stand structure attributes were also recognised as a crucial determinant of ground bryophyte communities in a naturally regenerated and planted forest in China (Yan et al. 2013). Finally, soil salinity, volumetric water content and vascular plant species cover proved to significantly affect the composition of bryophytes in Scots pine forests (Tilk et al. 2018). As a general rule, coniferous and deciduous trees provide different habitat conditions with respect to light intensity, moisture availability, litter deposition, soil $\mathrm{pH}$ and fertility (e.g. Augusto et al. 2002; Márialigeti et al. 2009). For these reasons, we suppose that coniferous and deciduous trees will harbour different bryophyte assemblages.

In the present study, we analysed the effect of different tree species growing in monospecific stands in an experimental forest on understorey bryophyte communities. Siemianice Experimental Forest (western Poland) is a research area unique on a global scale that comprises monoculture plots with 14 different tree species planted in 1970 and 1971 on the same type of soil substrate. The evaluation of the effect of tree species and other habitat factors on bryophytes in such an experimental forest seems to be highly beneficial compared to natural forest communities since the experimental setup allows for a convenient reduction of confounding factors such as differences in tree stand age, microclimate, topographic factors, admixture of other tree species and other external factors. To the best of our knowledge, there have been no studies concerning the direct effect of tree species on understorey bryophytes under such conditions. We assume that the 50-year period from planting the trees is sufficient to establish differentiated microhabitat conditions and create different ecological niches for bryophytes. Consequently, we hypothesise that tree species, albeit indirectly, has a major influence on bryophyte species composition and diversity in the forest floor.

The overall aims of the study were (1) to determine if bryophyte species richness and cover varies between plots with different tree species, between plots with deciduous and coniferous trees as well as 
between plots with native and alien to the flora of the region tree species; (2) to recognise the most important habitat factors influencing species richness and composition of understorey bryophyte communities; (3) to determine to what extent bryophyte species composition captured in ecological indicator values corresponds to the measured habitat variables; (4) to recognise tree species which are of particular conservation value in terms of preservation of the biodiversity of bryophytes in the forest interior.

\section{Materials and methods}

\section{Study area and sampling}

The study was conducted in the Siemianice Experimental Forest, W Poland $\left(51^{\circ} 14.87^{\prime} \mathrm{N}, 1^{\circ} 06.35^{\prime}\right.$ E, $150 \mathrm{~m}$ a. s. 1.). According to the updated Köppen-Geiger climate classification (Kottek et al. 2006), the study area is classified under a temperate-oceanic climate $(\mathrm{Cfb})$ with a mean temperature of $8.2{ }^{\circ} \mathrm{C}$ and mean annual precipitation of $591 \mathrm{~mm}$.

Soils in the experimental forest are composed of $80 \%$ sand and 15\% silt ( $c f$ Hobbie et al. 2006; Reich et al., 2005; Szymański 1982). Initially, the site constituted a stand of Pinus sylvestris L.; then tree felling, stump removal, and ploughing to a depth of $60 \mathrm{~cm}$ were applied (Dickie et al. 2010). A forest tree nursery was established at the turn of 1970/1971 and included seedlings of 14 species, namely Abies alba Mill., Acer platanoides L., A. pseudoplatanus L., Betula pendula Roth, Carpinus betulus L., Fagus sylvatica L., Larix decidua Mill., Picea abies (L.) H. Karst., Pinus nigra Arn., P. sylvestris L., Pseudotsuga menziesii (Mirb.) Franco, Quercus robur L., Q. rubra L., and Tilia cordata Mill. Hence, coniferous (6 tree species), deciduous (8 species), native trees (11 species) and trees alien to Poland (3 species) are represented in the forest. The seedlings were planted in $20 \times 20 \mathrm{~m}$ plots, with spacing of $1 \times 1 \mathrm{~m}$, in 2 adjacent areas, covering 2.4 ha in total (Reich et al. 2005; Szymański 1982). The number of plots for A. alba was 2 (the majority of $A$. alba trees on the third plot fell down several years ago); for A. platanoides, $A$. pseudoplatanus, B. pendula, C. betulus, F. sylvatica, P. nigra, P. sylvestris, Q. rubra, and T. cordata, 3; for
L. decidua, $P$. abies, $P$. menziesii, and $Q$. robur, 6 . The total number of plots $(n=53)$ includes plots representing deciduous $(n=27)$ and coniferous $(n=26)$ trees and native $(n=41)$ and alien $(n=12)$ trees.

Sampling plots of size $1 \times 1 \mathrm{~m}$ were located in the central part of each forest plot to avoid edge effects. Bryophyte and vascular plant species richness and cover were evaluated (see section hereafter). Then, 3 soil subsamples were collected to a depth of ca. $20 \mathrm{~cm}$ using a shovel; organic matter (O horizon) was removed before sampling. Collected subsamples were placed in foil bags and homogenised to create a single composite sample representative for each plot. Soils were transferred into new foil bags and stored at 4 ${ }^{\circ} \mathrm{C}$. Each sample was collected and processed using a sterile kit to avoid contamination. After sampling at a given plot, the shovel was cleaned, sterilized with $70 \%$ ethanol, and treated with fire. Altogether, 53 soil samples were collected on 3 and 4 June 2018. Soils were used for analyses of chemical properties (see section hereafter; see also Stefanowicz et al. 2021).

Bryophyte and vascular plant species richness, cover, and light intensity

Bryophyte and vascular plant species composition in each sampling plot were determined as follows. Each bryophyte sample was taken apart and studied in detail under a microscope to avoid overlooking any mixed species or hidden fragments of mosses and liverworts. The bryophyte material was deposited in the OSTR herbarium (University of Ostrava), the nomenclature of bryophytes follows Hill et al. (2006), while vascular plant species were identified according to Rutkowski (2014). Cover of bryophytes and vascular plants was estimated on a percentage scale within each sampling plot using digital photos of vegetation. The borders of each sampling plot were clearly marked with a coloured cord; then a Nikon D5300 Digital Camera attached to portable camera tripod was used to photograph vegetation cover. The photos were taken from $1.5 \mathrm{~m}$ above the ground at a downward angle of $90^{\circ}$ with the same field of view, resolution and other settings. A bubble level was used to ensure that the tripod, camera, and resulting images were exactly vertical. Subsequently, the coverage was estimated manually by using Motic Images Plus 2.0 
software (Hong Kong, Asia) and converted into a percentage of the plot surface (Rożek et al. 2020).

\section{Light intensity}

Light intensity ( $\mu \mathrm{mol} \mathrm{m} \mathrm{m}^{-2} \mathrm{~s}^{-1}$ ) was measured using a PAR Quantum Sensor (Kipp \& Zonen, The Netherlands). The measurements were taken in the middle of a cloudy day for 5 randomly selected locations within each plot at a height of $150 \mathrm{~cm}$ above the ground. Average values were treated as a single observation in subsequent analyses. The measurements were taken simultaneously during a very short time period (from 10:00 to 12:00) at all plots (Rożek et al. 2020).

\section{Chemical analyses of soils}

Soil samples were passed through a sieve $(2 \mathrm{~mm})$ and subjected to analyses for chemical properties (Stefanowicz et al. 2021). The $\mathrm{pH}$ in $\mathrm{H}_{2} \mathrm{O}$ (1:5; w:v) was measured with a Hach Lange HQ40D multi meter (ISO 10390:1994). The total and organic C content was analysed with a analyser RC-612 (Leco; ISO 10694:1995) and total $\mathrm{N}$ with a Foss Tecator 2300 Kjeltec Analyzer Unit following soil digestion in $\mathrm{H}_{2} \mathrm{SO}_{4}$ with Kjeltabs $\left(\mathrm{K}_{2} \mathrm{SO}_{4}+\mathrm{CuSO}_{4} \cdot 5 \mathrm{H}_{2} \mathrm{O}\right)$ in accordance with application AN 300. Samples for analyses of other elements, i.e. total $\mathrm{Ca}, \mathrm{K}, \mathrm{Mg}$, and $\mathrm{P}$, were digested with a Foss Tecator Digestor 40 unit in hot concentrated $\mathrm{HClO}_{4}$. Samples intended for analyses of exchangeable $\mathrm{Ca}^{2+}, \mathrm{K}^{+}$, and $\mathrm{Mg}^{2+}$ were shaken (Laboratory Shaker type 358S, elpan) three times for $1 \mathrm{~h}$ in $0.1 \mathrm{M} \mathrm{BaCl}_{2}$ (PN-EN ISO 11260:2011). Concentrations of elements in the extracts were analysed using flame atomic absorption spectrometry (Varian AA280 FS), with the exception of total P, which was measured with a Hach-Lange DR 3800 spectrophotometer, using the molybdenum-vanadate method. Content of available $\mathrm{P}$ (Olsen $\mathrm{P}$ ) was extracted with $0.5 \mathrm{M} \mathrm{NaHCO}$ (1:10; w:v) and measured with a Dionex ICS-1100 ion chromatograph (Olsen and Sommers 1982). $\mathrm{N}-\mathrm{NH}_{4}$ and $\mathrm{N}-\mathrm{NO}_{3}$ were extracted by shaking in $\mathrm{H}_{2} \mathrm{O}(1: 10$; w:v) and measured using Dionex DX-100 and Dionex ICS-1100 ion chromatographs. Certified reference materials were used for quality assurance of available/exchangeable element concentration analysis: ISE-859, ISE-912, and ISE995 (WEPAL). For calibration purposes, Six Cation Standard II and Seven Anion Standard II (Dionex) were used (Chmolowska et al. 2019; Stefanowicz et al. 2017, 2018, 2021).

Calculations and statistical analyses

First we assessed homoscedasticity through a BrownForsythe test. Second we carried out a one-way ANOVA with bryophyte species richness and cover being the dependent variables and the identity of tree species the categorical predictor. Given a significant ANOVA statistic, we finally carried out Tukey's HSD tests for unequal sample sizes to determine whether the differences between particular tree species were significant. Student's t-tests were performed in order to verify significant differences in the above-mentioned parameters between plots representing deciduous and coniferous trees. Prior to the analyses, the distribution normality of variables was verified by means of the Kolmogorov-Smirnov test. The nonparametric Mann-Whitney U test was applied for comparison between plots representing trees of native and alien origin.

Permutational multivariate analysis of variance (PERMANOVA) was performed to test for differences in bryophyte species composition between plots representing different tree species, deciduous and coniferous trees as well as native and alien trees (Anderson 2001). Due to unbalanced design type III Sum of Squares (SS) were used for partitioning of multivariate variation. Pair-wise comparisons among all pairs of tree species were calculated as multivariate pseudo-t statistics and $\mathrm{p}$ values obtained using permutation procedure. The analyses were based on the matrix of the presence/absence of bryophyte species using the Jaccard coefficient, with 999 permutations for each test. Subsequently, we evaluated which species were most responsible for differentiating bryophyte communities between plots representing deciduous and coniferous trees as well as native and alien trees, using similarity percentage routine (SIMPER; Clarke 1993). The analysis was based on the square-rooted matrix of bryophytes frequency in plots representing individual tree species; Bray-Curtis similarity index was used.

The matrix with mean values of habitat parameters and frequency of bryophyte species in a given plot type was created $(n=14)$. The plot type represents the plot with a given tree species. The frequency of bryophyte species was considered percentage of plots of 
a given type in which a given species occurs. Firstly, non-metric multidimensional scaling (NMDS) was used to visualise the pattern of similarities between different plot types in terms of species composition. All habitat parameters were passively fitted to the ordination space. Subsequently, factor analysis (FA) based on principal component analysis (PCA) was applied to obtain uncorrelated factors representing habitat parameters. The analysis was based on the matrix with mean values of habitat parameters in a given plot type. The factors with eigenvalues $>1$ were extracted according to Kaiser criterion and varimaxrotated to facilitate their interpretation. Then canonical correspondence analysis (CCA) was used to relate the frequency of bryophyte species to factors representing habitat conditions. A Monte Carlo permutation test based on 9999 random permutations was performed in order to assess the statistical significance of canonical axes (ter Braak and Smilauer 2002).

Next, factor analysis (FA) was applied on the data matrix including habitat parameters in individual sampling plots $(n=53)$. Then, we conducted forward stepwise multiple linear regression analysis (with a threshold of $\mathrm{P}<0.05$ to entry and remove) to investigate the effect of Factors derived from factor analysis on bryophyte species richness and cover. The analysis was based on the data matrix for individual sampling plots $(n=53)$. The procedure constitutes a combination of the forward selection and backward elimination. The initial models included only a regression constant and a predictor with the lowest input statistic (p-to-enter) was firstly entered into the model. Prior to the analysis, the potential collinearity of the predictors was checked by calculating the variance inflation factors (VIFs). A detailed residual analysis was performed to validate the regression model and to detect outliers. If studentised residuals greater than 3 in absolute value (corresponding to points more than 3 standard deviations from the fitted model) were detected, the outliers were excluded from the analysis. The Durbin-Watson statistic was calculated to evaluate the potential presence of a serial correlation of residuals.

The ecological indicator values were assigned to particular bryophyte species according to Ellenberg et al. (1991) and modified by Hill et al. (2007) classification. Based on bryophyte species composition, the mean indicator values were calculated for each plot. Next, associations between these values and selected habitat parameters were tested with Pearson correlation coefficients. The analysis was done to determine to what extent bryophyte species composition in the studied experimental forest captured in the mean ecological indicator values corresponds to the measured habitat variables. Following the Brown-Forsythe test to assess the equality of variances, Student's t-tests $(\mathrm{P}<0.05)$ were performed in order to verify significant differences in ecological indicator values ( $\mathrm{L}$ - light, $\mathrm{F}$ - moisture, $\mathrm{R}$ - reaction, $\mathrm{N}$ - nitrogen, human impact (hemeroby)) between plots representing deciduous and coniferous trees. Prior to the analyses, the distribution normality of variables was verified by means of the Kolmogorov-Smirnov test. Additionally, the ecological indicator values for forest bryophytes according to Bernhardt-Römermann et al. (2018) classification were used to analyse the proportions, based on the overall occurrence frequency of all recorded species, in plots representing deciduous and coniferous trees.

The statistical calculations were performed using STATISTICA 13 (StatSoft, Tulsa, OK), STATGRA PHICS CENTURION 18 (StatPoint, Inc), CANOCO 5 (Lepš and Šmilauer 2003), PAST 3.22 (Hammer et al. 2001) and PRIMER 7 statistical software (Primer-E, Plymouth UK; Anderson et al. 2016).

\section{Results}

Effect of tree species identity on bryophyte species richness and cover

Bryophyte species richness differed significantly between plots representing particular tree species (Fig. 1). The mean number of species per plot was significantly higher in Quercus robur, Picea abies, and Pinus sylvestris plots than in Q. rubra plots (ANOVA; $\mathrm{F}=2.89 ; \mathrm{P}=0.005$ ). The cover of bryophytes also differed between plots, being the highest in P. abies and Larix decidua plots (ANOVA; $\mathrm{F}=7.52 ; \mathrm{P}<0.001)$. The plots with coniferous trees were characterised by significantly higher bryophyte species richness and cover than those with deciduous trees (Student-t tests; $\mathrm{P}<0.05$ ). Concerning the comparison in terms of tree species of different origin, the plots with native trees were characterised by significantly higher bryophyte cover (U-Mann Whitney test; $\mathrm{P}<0.05)$. Bryophyte species richness was also 

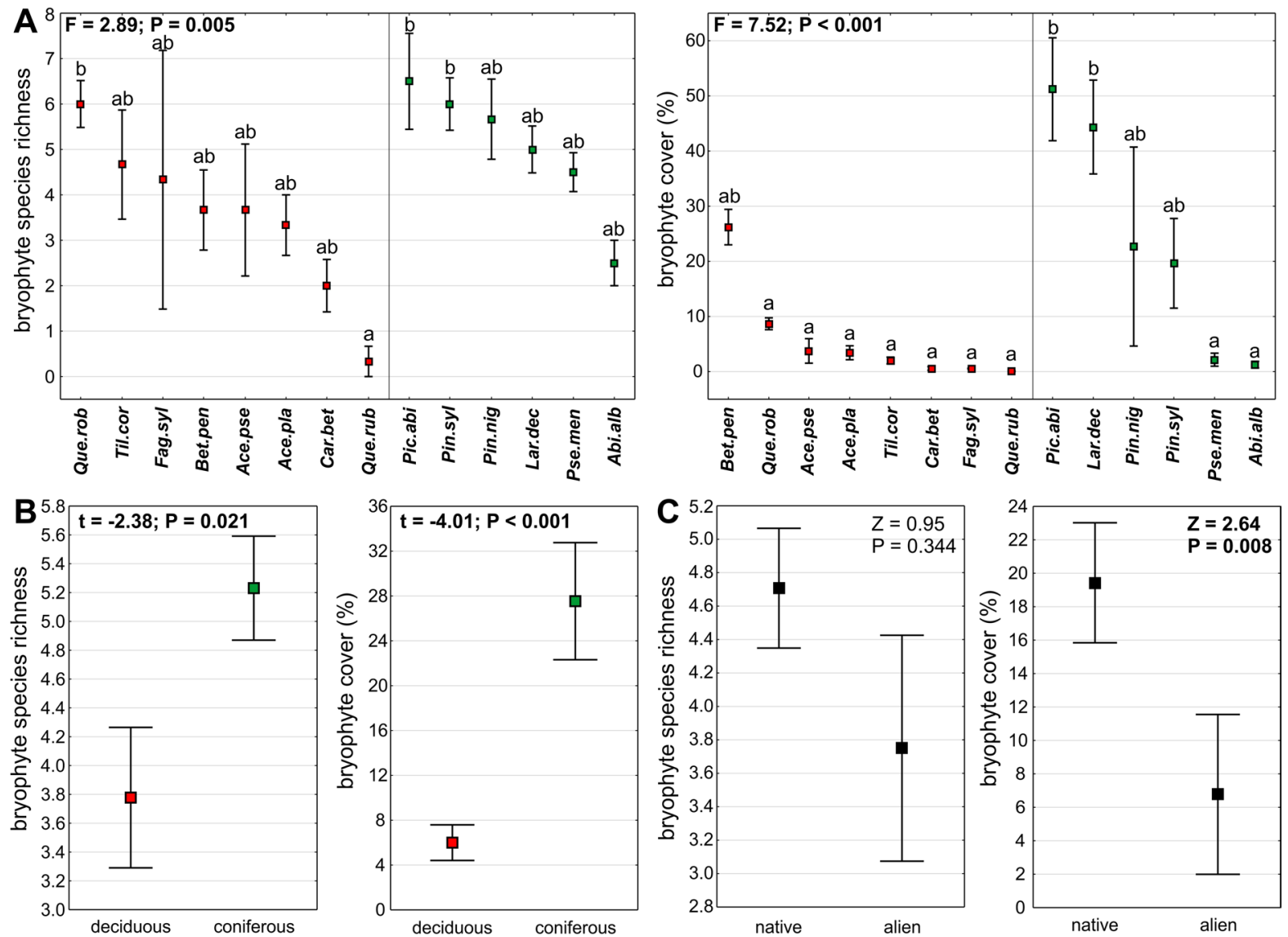

Fig. 1 Bryophyte species richness and cover (mean $\pm S E$ ) in the studied plots in relation to: particular tree species (A), deciduous and coniferous trees (B), native and alien tree species (C). The results of one-way ANOVA (A), Student-t test

(B), and U-Mann Whitney test (C) are provided. The various letters above the whiskers indicate statistically significant differences according to Tukey's HSD test $(\mathrm{P}<0.05)$

higher in these plots; however, the differences were not significant.

\section{Bryophyte species composition}

Altogether, 27 bryophyte species from 18 genera were recorded (Table S1). More specifically, one species of liverworts, 12 species representing 5 families of acrocarpous mosses and 14 species representing 6 families of pleurocarpous mosses were identified. The total number of species found in particular plots ranged from 1 (Quercus rubra) to 19 (Picea abies). As regards grouping of plots into deciduous and coniferous, from a total 27 recorded species, 19 were non-specific and occurred in both plot types; plots with deciduous trees harboured 4 exclusive species

(i.e. Amblystegium serpens, Aulacomnium androgynum, Plagiothecium succulentum, and Rhytidiadelphus squarrosus), whereas plots with coniferous trees also had 4 exclusive species (i.e. Ceratodon purpureus, Dicranoweisia cirrata, Dicranum montanum, and Dicranum tauricum).

PERMANOVA results showed that species composition differed significantly between plots representing different tree species $(\mathrm{F}=1.63, \mathrm{P}<0.001)$, between plots with deciduous and coniferous trees $(\mathrm{F}=4.02, \mathrm{P}<0.001)$ and between plots with native and alien trees $(\mathrm{F}=2.44, \mathrm{P}<0.001)$. Pairwise comparisons between plots representing different tree species showed that most of significant differences were recorded between deciduous and coniferous tree species (Table 1). NMDS ordination 
Table 1 PERMANOVA pairwise comparisons of bryophyte species composition between plots representing different tree species. Lower diagonal $-\mathrm{P}$ values by permutation, upper diagonal - average similarities between groups (\%); values in bold are significant. Colour of the cell filling in the upper diagonal corresponds to the degree of similarity between the groups: dark red: $0-5$, red: $5-10$, orange: $10-15$, yellow: 15-20, yellow-green: 20-25, light green: $25-30$, dark green: $>30$

\begin{tabular}{|c|c|c|c|c|c|c|c|c|c|c|c|c|c|c|c|c|}
\hline \multirow{2}{*}{\multicolumn{2}{|c|}{ Tree species }} & \multicolumn{8}{|c|}{ Deciduous trees } & \multicolumn{7}{|c|}{ Coniferous trees } \\
\hline & & Ace. pla & Ace. pse & Bet. pen & Car. bet & Fag. syl & Que. rob & Que. rub & Til. cor & Abi. alb & Lar. dec & Pic. abi & Pin. nig & Pin. syl & Pse. men & \\
\hline \multirow{8}{*}{ 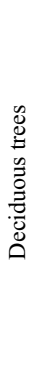 } & Ace. pla & & 25.503 & 14.259 & 11.111 & 8.148 & 19.506 & 0.000 & 29.352 & 5.556 & 18.175 & 19.749 & 17.451 & 10.67 & 8.135 & \\
\hline & Ace. pse & 0.300 & & 12.989 & 6.217 & 9.109 & 24.804 & 2.778 & 25.225 & 9.921 & 16.125 & 14.305 & 15.054 & 11.724 & 8.325 & \\
\hline & Bet. pen & 0.103 & 0.296 & & 10.556 & 11.191 & 14.899 & 0.000 & 14.815 & 17.381 & 20.741 & 19.765 & 8.549 & 21.125 & 9.678 & \\
\hline & Car. bet & 0.097 & 0.413 & 0.603 & & 12.290 & 12.456 & 8.333 & 10.600 & 20.833 & 15.331 & 18.181 & 15.847 & 15.926 & 11.210 & \\
\hline & Fag. syl & 0.098 & 0.280 & 0.502 & 1.000 & & 11.585 & 0.000 & 6.918 & 2.904 & 10.273 & 12.130 & 12.098 & 12.186 & 10.859 & \\
\hline & Que. rob & 0.038 & 0.631 & 0.059 & 0.211 & 0.067 & & 6.954 & 26.041 & 16.005 & 25.729 & 25.450 & 25.135 & 19.464 & 16.276 & \\
\hline & Que. rub & 0.099 & 0.296 & 0.107 & 1.000 & 0.404 & 0.037 & & 9.722 & 20.833 & 8.611 & 8.218 & 9.325 & 8.492 & 8.333 & \\
\hline & Til. cor & 0.302 & 0.499 & 0.338 & 0.305 & 0.105 & 0.265 & 0.211 & & 26.667 & 29.222 & 23.855 & 33.127 & 25.133 & 22.569 & 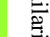 \\
\hline \multirow{7}{*}{ 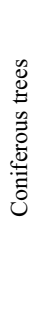 } & Abi. alb & 0.104 & 0.177 & 0.502 & 0.593 & 0.101 & 0.081 & 1.000 & 0.399 & & 28.363 & 25.218 & 20.714 & 36.806 & 22.877 & \\
\hline & Lar. dec & 0.016 & 0.020 & 0.063 & 0.143 & 0.020 & 0.065 & 0.042 & 0.167 & 0.204 & & 32.488 & 31.259 & 35.605 & 29.566 & \\
\hline & Pic. abi & 0.034 & 0.056 & 0.265 & 0.566 & 0.106 & 0.377 & 0.038 & 0.216 & 0.350 & 0.502 & & 26.452 & 30.248 & 23.009 & \\
\hline & Pin. nig & 0.117 & 0.084 & 0.098 & 0.612 & 0.382 & 0.205 & 0.090 & 0.810 & 0.102 & 0.206 & 0.327 & & 28.084 & 28.521 & \\
\hline & Pin. syl & 0.097 & 0.099 & 0.322 & 0.420 & 0.198 & 0.021 & 0.105 & 0.114 & 0.806 & 0.344 & 0.435 & 0.217 & & 29.204 & \\
\hline & Pse. men & 0.014 & 0.013 & 0.010 & 0.090 & 0.035 & 0.004 & 0.033 & 0.034 & 0.127 & 0.103 & 0.063 & 0.301 & 0.200 & & \\
\hline & \multicolumn{16}{|c|}{$P$ values by permutation } \\
\hline
\end{tabular}

diagram also clearly separated the plots with coniferous trees from plots representing deciduous trees (Fig. S1). The differences were the most pronounced for the coniferous trees $P$. menziesii and $L$. decidua that differed significantly from 7 and 4 different deciduous tree species, respectively (Table 1). The plots representing different coniferous tree species did not differ significantly between each other and the average similarity of bryophyte species composition was always greater than $20 \%$. Regarding differences within deciduous tree species, $Q$. robur differed significantly from A. platanoides and $Q$. rubra plots.

Based on the SIMPER analysis we identified which bryophyte species contributed disportionally to the differentiation of deciduous and coniferous tree plots as well as native and alien tree plots (Table S2). Sixteen bryophyte species proved to more abundant in plots with coniferous trees, whereas only eleven proved to be associated to a greater extent with plots with deciduous trees. Only nine species turned out to be more abundant in plots with alien tree species.
Relationships between habitat properties and bryophytes

The relationships between bryophyte species composition and factors representing habitat conditions were determined by means of CCA (Fig. 2). The first axis and all canonical axes taken together were statistically significant $(\mathrm{F}=2.0, \mathrm{P}=0.020$ and $\mathrm{F}=1.5$, $\mathrm{P}=0.017$, respectively). The ordination diagram distinguished plots with coniferous trees (the lower left side of the graph), with the exception of Pinus nigra plots, from plots representing deciduous trees. Moving from the left to the right side of the diagram, soil $\mathrm{pH}$ and macronutrient concentrations increase. Plots with Acer spp. and Tilia cordata were characterised by the highest $\mathrm{K}, \mathrm{Mg}$, and $\mathrm{Ca}$ concentrations in soil and the highest soil $\mathrm{pH}$; the occurrence of four bryophyte species, i.e. Rhytidiadelphus squarrosus, Plagiomnium affine, Atrichum undulatum, and Amblystegium serpens, was most strongly associated with these plots. The second clear association occurs in the lower left part of the graph, where species preferring high $\mathrm{C}, \mathrm{P}$ and $\mathrm{N}-\mathrm{NO}_{3}$ contents in soil (high values of 


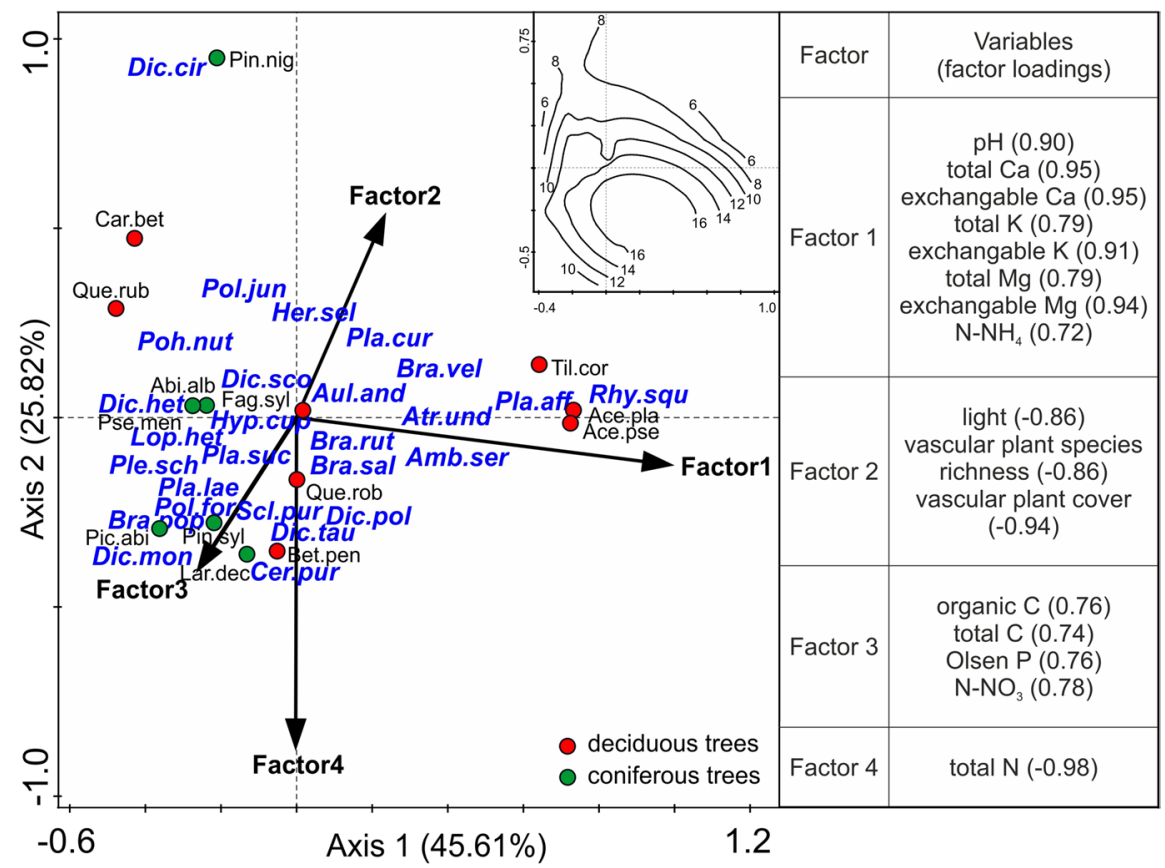

Fig. 2 Canonical correspondence analysis (CCA) ordination diagram showing the relationship between bryophyte species, Factors associated with habitat conditions and plots representing particular tree species. Bryophyte species richness contour lines are provided on the inset graph. Factors derived from factor analysis are provided in the figure; only variables with factor loadings greater than 0.7 are listed Abbreviations of species are as follows: Bryophytes: Amb.ser - Amblystegium serpens; Atr.und - Atrichum undulatum; Aul.and - Aulacomnium androgynum; Bra.pop - Brachythecium populeum; Bra. rut - Brachythecium rutabulum; Bra.sal - Brachythecium salebrosum; Bra.vel - Brachythecium velutinum; Cer.pur - Ceratodon purpureus; Dic.het - Dicranella heteromalla; Dic.cir Dicranoweisia cirrata; Dic.mon - Dicranum montanum; Dic. pol - Dicranum polysetum; Dic.sco - Dicranum scoparium;

Factor 3) and high light intensity as well as high vascular plant cover and richness (opposite side of Factor 2 vector) were grouped. The occurrence of Dicranum montanum, D. tauricum, Ceratodon purpureus, Brachythecium populeum, Polytrichum formosum, Plagiothecium laetum, Pleurozium schreberi, and Lophocolea heterophylla was mainly associated with plots of coniferous trees and/or Betula pendula plots. The second axis determined the gradient of increasing total $\mathrm{N}$ concentrations in soil. Plot representing Pinus nigra with Dicranoweisia cirrata occurring only under this tree species was located in the upper side of the diagram on the opposite side of Factor 4 vector. Brachythecium rutabulum and Hypnum
Dic.tau - Dicranum tauricum; Her.sel - Herzogiella seligeri; Hyp.cup - Hypnum cupressiforme; Lop.het - Lophocolea heterophylla; Pla.aff - Plagiomnium affine; Pla.cur - Plagiothecium curvifolium; Pla.lae - Plagiothecium laetum; Pla.suc Plagiothecium succulentum; Ple.sch - Pleurozium schreberi; Poh.nut - Pohlia nutans; Pol.for - Polytrichum formosum; Pol.jun - Polytrichum juniperinum; Rhy.squ - Rhytidiadelphus squarrosus; Scl.pur - Scleropodium purum. Trees: Ace. pla - Acer platanoides; Ace.pse - Acer pseudplatanus; Bet. pen - Betula pendula; Car.bet - Carpinus betulus; Fag. syl Fagus sylvatica; Que.rob - Quercus robur; Que.rub - Quercus rubra; Til.cor - Tilia cordata; Abi.alb - Abies alba; Lar.dec - Larix decidua; Pic.abi - Picea abies; Pin.nig - Pinus nigra; Pin.syl-Pinus sylvestris; Pse.men - Pseudotsuga menziesii

cupressiforme were located in the central part of the diagram. These species were present in most plot types (at least in 11 different plot types) and could be considered as indifferent with respect to measured habitat parameters and tree species.

Based on the whole data matrix, factor analysis reduced 16 variables to four factors with eigenvalues $>1$ that jointly explained $76.66 \%$ of the total variation (Table 2). Factor 1 was associated with soil $\mathrm{pH}$ and essential macronutrient levels (total and exchangeable $\mathrm{K}, \mathrm{Mg}, \mathrm{Ca}$ ). Factor 2 was related to soil fertility and referred to contents of total and organic carbon and total and $\mathrm{NO}_{3}$-form nitrogen. Factor 3 was negatively associated with vascular plant species 
Table 2 Factors derived from habitat properties (including soil parameters, light intensity and vascular plant variables). Factor loadings are given in parentheses; only variables with factor loadings greater than 0.7 are listed. The percentage of explained variance for each Factor is provided

\begin{tabular}{lll}
\hline Factor no & $\begin{array}{l}\text { Variables } \\
\text { (factor loadings) }\end{array}$ & $\begin{array}{c}\text { Variance } \\
\text { explained } \\
(\%)\end{array}$ \\
\hline Factor 1 & $\mathrm{pH}(0.82)$, total $\mathrm{Mg}(0.73)$, exchangable $\mathrm{Mg}(0.89)$, total $\mathrm{K}(0.70)$, total Ca $(0.78)$, \\
& exchangable $\mathrm{K}(0.85)$, exchangable $\mathrm{Ca}(0.88)$ & 46.95 \\
Factor 2 & organic $\mathrm{C}(0.84)$, total $\mathrm{C}(0.84), \mathrm{N}-\mathrm{NO}_{3}(0.77)$ & 12.60 \\
Factor 3 & vascular plant species richness $(-0.87)$, vascular plant cover $(-0.88)$ & 10.50 \\
Factor 4 & light $(-0.72)$, Olsen $\mathrm{P}(0.81)$ & 6.61 \\
\hline
\end{tabular}

richness and cover. Light was highly negatively correlated with Factor 4, whereas Olsen P positively.

The results of the multiple stepwise regression analysis are presented in Table 3. A forward stepwise procedure with four Factors derived from factor analysis as predictor factors and bryophyte species richness as the dependent variable revealed that only Factors 3 and 4 were included in the model $(F=10.38$; $\mathrm{P}<0.001)$. Both Factors were negatively related to bryophyte species richness. This means that vascular plants and light positively influenced bryophyte species richness whereas high concentrations of $\mathrm{P}$ negatively affected the number of bryophyte species. As regards bryophyte cover, Factors 1 and 3 were

Table 3 Result of forward stepwise multiple regression analysis for the effect of Factors related to habitat parameters derived from factor analysis on bryophyte species richness and cover (for Factor characteristics see Table 2). Standardized $\beta$ macronutrient concentrations, showed a negative effect.

Bryophyte indicator values

The results showed a significant positive correlation $(\mathrm{P}<0.05)$ between mean indicator value $\mathrm{R}$ (reaction) and soil pH (Table 4; Fig. S2). Moreover, indicator value $R$ was also significantly related to both total and exchangeable $\mathrm{Ca}$ concentrations in soil as well as macronutrient concentrations $(\mathrm{K}$ and $\mathrm{Mg}$ ). Both nitrate form of nitrogen $\left(\mathrm{N}-\mathrm{NO}_{3}\right)$ and ammonium $\left(\mathrm{N}-\mathrm{NH}_{4}\right)$ were significantly and positively correlated with mean indicator value $\mathrm{N}$. Soil $\mathrm{pH}$ and concen-

coefficients follow from standardization of variables to a mean of 0 and a standard deviation of 1 . Coefficients of determination $\left(\mathrm{R}^{2}\right)$ of the whole model are provided. Factors are listed according to $\mathrm{P}$-value

\begin{tabular}{|c|c|c|c|c|c|}
\hline & Standardized $\beta$ coefficient & SE for $\beta$ coefficient & $\mathrm{t}$ & $\mathrm{P}$ & Model $\mathrm{R}^{2}$ \\
\hline \multicolumn{6}{|c|}{ Bryophyte species richness } \\
\hline Constant & & & 16.75 & $<0.001$ & 0.30 \\
\hline Factor 3 & -0.48 & 0.12 & -4.01 & $<0.001$ & \\
\hline Factor 4 & -0.26 & 0.12 & -2.16 & 0.036 & \\
\hline \multicolumn{6}{|c|}{ Bryophyte cover } \\
\hline Constant & & & 6.64 & $<0.001$ & 0.33 \\
\hline Factor 3 & -0.49 & 0.12 & -4.14 & $<0.001$ & \\
\hline Factor 1 & -0.30 & 0.12 & -2.57 & 0.013 & \\
\hline
\end{tabular}

included in the model $(\mathrm{F}=11.63 ; \mathrm{P}<0.001)$. As for species richness, vascular plant species richness and cover were positively related to bryophyte cover; whereas Factor 1, related to soil $\mathrm{pH}$ and essential trations of $\mathrm{Ca}, \mathrm{K}$ and $\mathrm{Mg}$ and carbon content were also positively related to mean indicator value N. A significant relation was not recorded for mean indicator value L (light) and neither light nor other soil parameters. 
Table 4 Pearson correlation coefficients for means of L, R, $\mathrm{N}$ indicator values (according to Ellenberg et al. (1991) and modified by Hill et al. (2007) classification) in the studied plots and measured habitat parameters. Significant correlations $(\mathrm{P}<0.05)$ are provided in bold

\begin{tabular}{|c|c|c|c|}
\hline & $\begin{array}{l}\text { Mean R } \\
\text { (reaction) }\end{array}$ & $\begin{array}{l}\text { Mean N } \\
\text { (nitrogen) }\end{array}$ & $\begin{array}{l}\text { Mean L } \\
\text { (light) }\end{array}$ \\
\hline light & -0.09 & -0.22 & 0.22 \\
\hline $\mathrm{pH}$ & $0.46 * *$ & $0.34 *$ & -0.23 \\
\hline total $\mathrm{Ca}$ & $0.45 * *$ & $0.43 * *$ & -0.20 \\
\hline exchangeable $\mathrm{Ca}$ & $0.52 * * *$ & $0.47 * * *$ & -0.15 \\
\hline Olsen P & 0.09 & 0.14 & 0.09 \\
\hline total $\mathrm{K}$ & $0.45 * *$ & $0.51 * * *$ & -0.13 \\
\hline exchangeable $\mathrm{K}$ & $0.41 * *$ & $0.43 * *$ & -0.18 \\
\hline total $\mathrm{Mg}$ & $0.47 * * *$ & $0.52 * * *$ & -0.14 \\
\hline exchangeable $\mathrm{Mg}$ & $0.49 * * *$ & $0.47 * * *$ & -0.14 \\
\hline total C & 0.28 & $0.32 *$ & -0.11 \\
\hline organic $\mathrm{C}$ & 0.26 & $0.31 *$ & -0.11 \\
\hline total $\mathrm{N}$ & 0.02 & 0.10 & -0.21 \\
\hline $\mathrm{N}-\mathrm{NH}_{4}$ & $0.31 *$ & $0.34 *$ & -0.03 \\
\hline $\mathrm{N}-\mathrm{NO}_{3}$ & 0.21 & $0.35 *$ & -0.10 \\
\hline
\end{tabular}

Concerning the comparison of ecological indicator values between plots with deciduous and coniferous trees, the latter ones were characterised by significantly lower $\mathrm{F}$ (moisture) and $\mathrm{R}$ (reaction) values (Student-t tests; $\mathrm{P}<0.05$ ). The $\mathrm{N}$ (nitrogen) values were also lower in plots with coniferous trees; however, the differences were not significant. For both deciduous and coniferous plots, L (light) values were highly variable and the mean $\mathrm{L}$ was nearly identical in plots with deciduous and coniferous trees. The indicator values of human impact (hemeroby) also did not differ significantly between these two plot types (Fig. S3).

Based on the overall occurrence frequency of bryophyte species, the comparison of the proportions of bryophytes representing ecological indicator values according to Bernhardt-Römermann et al. (2018) between plots with deciduous and coniferous trees gave consistent results. The greater frequencies of bryophytes preferring lower $\mathrm{pH}$, drier places and less nutrients in soil were found in plots with coniferous trees. Moreover, in these plots a greater proportion of species largely restricted to closed forests were noted compared to plots with deciduous trees (Fig. S4).

\section{Discussion}

In the present study we assessed for the first time the impact of 14 tree species growing in monoculture plots and that of related habitat parameters on bryophyte species composition, richness and abundance. Our study showed that both overstorey tree species and various habitat parameters including certain soil factors, light conditions and vascular plant layer had a great impact on ground bryophyte communities that emerged in the experimental forest 50 years after its establishment.

\section{Effect of light conditions}

Light intensity had a positive impact on bryophyte species richness. Light availability affects bryophyte species composition (e.g. Humphrey et al. 2002; Tinya et al. 2009) due to the different light requirements of particular species. Forest floor bryophytes have relatively low light demands. They have an evolutionarily set slower rate of photosynthesis and also due to the fact that they lack stomata and cuticle, they cannot directly control water loss and thus they are dependent on the water available in the environment (Proctor 2008). The effect of canopy tightness and the resulting shading may contribute to retaining moisture, but on the other hand, also decrease the amount of water reaching the forest floor. Moreover, light reaching the ground can directly affect soil temperature and thereby increase evaporation and decrease humidity on the microhabitat level (von Arx et al. 2012). Probably due to these complex relationships, there is no consensus about the definite effect of light availability on the ground bryophyte layer in the literature. Some studies suggested no significant relationship between light conditions and bryophyte species richness (e.g. Humphrey et al. 2002; Mills and MacDonald 2004). Tinya et al. (2009) found a significant relation between total cover of ground floor bryophytes and light, while species richness was not dependent on light. On the other hand, Moora et al. (2007) found that bryophyte species richness was positively related to local light availability. We found that light intensity enhanced bryophyte richness and significantly affects 
species composition. We believe that it is directly related to the effect of tree species. The highest bryophyte species richness were observed in plots with conifers, such as Pinus spp., Larix decidua and Picea abies, as well as from Quercus robur plots. The highest light intensities were also found under these species of coniferous trees (see also Rożek et al. 2020). In contrast, plots with Abies alba, Tilia cordata, $Q$. rubra, Fagus sylvatica, and Acer spp. were characterised by high shading conditions which could limit the growth and occurrence of certain light-requiring species, such as Dicranum scoparium, Polytrichum juniperinum, Scleropodium purum, and Ceratodon purpureus (see Table S1). This suggests that light availability might decrease below a critical threshold for some bryophytes, which results in a lower species richness in the most shaded plots. Interestingly, the mean L (light) indicator values based on species composition did not differ significantly between deciduous and coniferous plots. It is worth noting, however, that in coniferous plots where the light intensity was the highest (see also Rożek et al. 2020), the values of the F (moisture) indicator were much lower than in deciduous plots. Such a result suggests that habitat moisture, which indirectly results from light conditions in the forest floor, is a more important factor determining the occurrence of particular species. A second possible explanation is related to the previous observations made by Ewald (2009), who found that Ellenberg indicator values for ground bryophytes did not significantly predict measured habitat parameters in mountain forests and bryophyte indication proved to be particularly poor for light. Such a result could be also caused by a high proportion of indifferent species with a wide range of tolerance to light conditions. Finally, one should keep in mind that the current bryophyte species composition may result more from past light regimes than from the present light conditions, a phenomenon associated with the slow change of species pool similarly as it has been suggested for understory vascular plant communities (Thomas et al. 1999).

Importance of soil chemical parameters

Soil $\mathrm{pH}$ and content of macronutrients in soil proved to affect bryophyte cover. This effect seems to be directly related to the influence of tree species since the plots of particular species differed significantly in terms of soil $\mathrm{pH}$ and base cation concentrations (Stefanowicz et al. 2021). More acidic soil $\mathrm{pH}$ and lower concentrations of earth-alkaline cation concentrations are often found under coniferous trees compared to deciduous ones (Augusto et al. 2002, 2003; Nordén 1994). The same concerns the studied experimental forest, in which plots with conifers had significantly lower soil pH (Rożek et al. 2020; Stefanowicz et al. 2021). This is reflected in the increased cover of bryophytes in plots with coniferous trees. However, this also depends on particular coniferous tree species. The largest coverage of bryophytes was recorded in the plots with Pinus spp., Picea abies, and Larix decidua; whereas plots with Pseudotsuga menziesii and Abies alba were characterised by relatively low bryophyte coverage, which was comparable to those recorded in plots with deciduous trees. This is in line with the acidifying capabilities of coniferous species reported by Augusto et al. (2003) who found that $P$. sylvestris and $P$. abies have the greatest soil acidifying capabilities; whereas $P$. menziesii and A. alba had moderate effect on soil acidity. The shady conditions under the latter two species may additionally limit the coverage of bryophytes. Plots of Acer spp. and Tilia cordata trees were characterised by the highest soil $\mathrm{pH}$ and the concentrations of base cations (Stefanowicz et al. 2021). These tree species have been recognised to have low soil acidifying ability (Augusto et al. 2003), and bryophyte cover was relatively low under these deciduous trees. The cover of bryophytes may be limited in these plots, firstly, by a lower abundance or lack of species confined to extremely acidic and acidic substrates (e.g. Pleurozium schreberi, Polytrichum juniperinum, Dicranum scoparium), and, secondly, by a large amount of litter constituting a mechanical barrier that limits the amount of soil substrate available for bryophyte development. Although we recorded species that previously were found to be associated with leaf litter, e.g. Brachythecium rutabulum (see Bates 2008), this species was frequently noted in plots with both deciduous and coniferous trees. Apart from the distinct effect of soil $\mathrm{pH}$ on the coverage of bryophytes, the species composition also clearly responded to this factor. This is demonstrated by significant differences in species composition between plots with deciduous and coniferous trees, significantly lower $\mathrm{R}$ (reaction) indicator values for plots with coniferous trees and most importantly by a positive correlation of mean $\mathrm{R}$ (reaction) indicator 
values with soil $\mathrm{pH}$. The higher $\mathrm{pH}$ of the forest bottom under coniferous trees is certainly also related to the rate of nutrient decomposition in the soil and the consequent amount of humus. A lower proportion of nutrients reduces the diversity of vascular plants in the herb layer, which do not compete significantly with bryophytes and results in a higher proportion of bryophyte species in these areas.

We did not find a significant impact of organic carbon and nitrogen contents in soil on bryophyte diversity and abundance. This may be due to relatively slight differences in the content of these elements between plots with different tree species (Rożek et al. 2020; Stefanowicz et al. 2021) that would potentially result in changes of total species number. On the other hand, we found a significant correlation between organic $\mathrm{C}, \mathrm{NH}_{4}$ and $\mathrm{NO}_{3}$ forms of nitrogen concentrations in soil and mean $\mathrm{N}$ (nitrogen) indicator value based on bryophyte species composition in plots. This shows that species richness and abundance of bryophyte cover may not be a sufficient determinant of the effect of soil fertility conditions, while changes in species composition are of key importance. This is a known phenomenon previously reported in the case of vascular plants in forests, in which gradual replacement of oligotrophic species by eutrophic species as a response to eutrophication was observed with a simultaneous absence of significant changes in species richness (Dirnböck et al. 2014).

Interaction between ground bryophytes and understory vascular plant layer

An interesting result concerns the positive relationship between the diversity/cover of bryophytes and vascular plants inhabiting forest floor. Many studies revealed that vascular plants negatively affect the diversity and abundance of bryophytes (e.g. Bergamini et al. 2001; Löbel et al. 2006; Virtanen et al. 2000; Yan et al. 2013). Such an effect was most frequently explained by competition between these two groups. However, most studies concerned grassland communities in which the herbaceous plant layer is, as a rule, significantly more developed than in the temperate forests. As regards forests, Fojcik et al. (2019) also revealed the negative impact of herbaceous plants on the total coverage of bryophytes in a managed temperate mixed forest in Poland. Similarly, Turkington et al. (1998) showed that the addition of NPK fertilizer to a nutrient-poor boreal forest ecosystem resulted in an intensive growth of vascular plants, mainly grasses, which at the same time caused a decrease in bryophyte cover. Contrastingly, in our study, we observed a positive relationship between vascular plant cover and bryophyte cover. This fact can be explained in two different ways. Firstly, vascular plant cover was not dominated by expansive grasses and sedges that could easily eliminate bryophytes from the forest floor (Chmura and Sierka 2007), and vascular plant cover was relatively low in the plots (see Rożek et al. 2020). This, in turn, is in line with the observations of Ingerpuu et al. (2005), who showed that even in grassland communities, positive interactions between bryophytes and vascular plants prevail when density of plant cover is low. Secondly, the plots with coniferous trees were richer in both bryophytes and vascular plants, while deciduous plots were characterised by a thick leaf litter cover acting as a mechanical and/or chemical barrier that limits the development of both forest-floor bryophytes and vascular plant species (Evans et al. 2012; Startsev et al. 2008). Soils in the plots with coniferous trees were characterised by lower macronutrient concentrations compared to deciduous ones, and this could indicate that asymmetry of competition between bryophytes and vascular plants is rather low as it is under nutrient limitation conditions (Rydin 2008). The higher cover of bryophytes in the plots with coniferous trees could also be associated with generally lower soil fertility since the total biomass of mosses, as a rule, decreases with increasing fertility (Mäkipää et al. 2000). Further to the above, vascular plants can have a positive effect on bryophytes by providing better microclimatic conditions for their growth. It has been suggested that this mechanism occurs in temperate forests in Hungary (Márialigeti et al. 2009, 2016).

Comparison of effects between deciduous/coniferous and native/alien trees

The higher species richness and cover of bryophytes under coniferous trees compared to deciduous trees supports that in forests dominated by conifers, bryophytes are an important component in terms of the biomass they provide (Jiang et al. 2018; Mäkipää et al. 2000), in contrast to deciduous forests, where forest floor bryophytes are often of little significance (Startsev et al. 2008). The higher bryophyte coverage in coniferous plots can certainly be related to the more favourable understorey microhabitat conditions 
under conifers (Bartemucci et al. 2006), while litter from deciduous trees proved to have a physical and/ or chemical inhibitory effect (Márialigeti et al. 2009; Startsev et al. 2008). Differences in bryophyte communities between conifer-dominated and deciduousdominated stands clearly confirm the occurrence of this phenomenon (e.g. Bartels et al. 2018). Nevertheless, a given tree species is of great importance in shaping the specific microhabitat. For example, in the case of bryophyte coverage, conifers differ from each other in their effect since we recorded significantly lower cover of bryophytes in Abies alba and Pseudotsuga menziesii plots compared to Picea abies and Larix decidua plots. Species richness within plots of deciduous trees also depends on tree species. Quercus robur was clearly the leader, both in terms of the mean species richness per plot and the total number of recorded species, which were comparable to the most species-rich plots of conifers.

Two main tree species that are involved in forming a stand consistent with the natural mixed oak-pine forest (Querco roboris-Pinetum), i.e. Quercus robur and Pinus sylvestris, provided the greatest species richness of ground bryophytes. Furthermore, bryophyte composition in the plots representing these two tree species is relatively diverse. As many as 10 species were exclusive for $Q$. robur plots, 3 species for P. sylvestris plots, and 8 were common to both plot types. Altogether this accounts for $77.8 \%$ of all species recorded in the experimental forest. This shows that the promotion in forestry of tree species forming plant communities consistent with the natural habitat is highly beneficial for the biodiversity of ground bryophytes.

Our results showed that, in general, alien to Poland tree species (i.e. Quercus rubra, Pseudotsuga menziesii, and Pinus nigra) negatively affected bryophyte communities. The strongest adverse effect on diversity and abundance of bryophytes was recorded in $Q$. rubra plots. It is known that this invasive tree has a negative effect on native plant species richness and abundance both in old-growth and secondary forests (Chmura 2013; Woziwoda et al. 2014). In addition, Q. rubra has a strong influence on soil properties (Ferré and Comolli 2020). With respect to the impact of $Q$. rubra on bryophytes, the literature reports are rather poor and divergent. Woziwoda et al. (2017) found a high number of native epiphytic bryophytes on the bark of $Q$. rubra and concluded that this tree species could successfully provide a functional alternative to oaks native to Poland $(Q$. robur and $Q$. petraea). On the other hand, Jagodziński et al. (2018) reported fewer epiphytes in $Q$. rubra stands than in $Q$. robur in a reclaimed lignite mine spoil heap. As regards ground bryophytes, a report concerning a disturbed habitat showed that $Q$. rubra did not have a negative impact on ground bryophytes and the number of species was similar to that under the $Q$. robur canopy (Jagodziński et al. 2018). Contrary to this, we found a significantly lower number of bryophyte species in $Q$. rubra compared to $Q$. robur plots. We can explain the negative influence of $Q$. rubra by the limiting effect of thick leaf litter accumulation on the forest floor as well as the high shading generated by this species. The leaf litter of $Q$. rubra decomposes very slowly (Dobrylovska 2001), and involves high production of barely decomposable material which accumulates on the forest floor and which is probably responsible for the sparse bryophyte cover. A similar observation was made by Woziwoda et al. (2017) in Pinus sylvestris-Quercus rubra secondary forests. In our opinion, the adverse effect of $Q$. rubra should be considered strong because after 50 years in the whole experimental forest, we recorded as many as 18 different bryophyte species in $Q$. robur plots and only one species, i.e. Hypnum cupressiforme, in Q. rubra plots. As regards the second alien species, i.e. P. menziesii, the negative effect concerns only the cover of bryophytes compared to native coniferous trees such as Picea abies and Larix decidua; mean species richness of bryophytes did not differ significantly from the remaining coniferous and deciduous trees. Finally, we did not observe significant differences in either species richness or cover of bryophytes between $P$. nigra (alien) and $P$. sylvestris (native) plots, although the species composition was slightly different between plots of these two tree species.

Effect of tree species identity on bryophytes

Despite the fact that different tree species grow in the immediate vicinity in one experimental forest, we have observed a great effect of the tree species on bryophyte species composition, richness and abundance of ground bryophytes. Therefore we can assume that the changes in dominant tree species in a forest stand may alter many dependent bryophyte species. This can be extremely important in the context of climate 
changes that may affect bryophytes directly, but also indirectly through changes in the stand species composition. Thus the range contraction of certain forest tree species would have also serious consequences for ground bryophytes. With regard to temperate forests coniferous species, such as $L$. decidua, P. abies, $P$. sylvestris, and pioneer deciduous trees, e.g. B. pen$d u l a$, are predicted to have a vast range contraction in central and eastern Europe (Schueler et al. 2014; Dyderski et al. 2018). Since we recorded both the greatest bryophyte species richness and abundance under these tree species, parallel reduction of ground bryophyte diversity can be expected. A great species richness of bryophytes was also associated with Q. robur trees, which also proved to be a refuge for rare epiphytic bryophytes and lichens (Király and Ódor 2010; Kubiak and Osyczka 2017); nevertheless although $Q$. robur tends to gain in range as the climate warms, it will lose much of its currently occupied range (Dyderski et al. 2018). Consequently, in addition to bioclimatic factors, which were recognised as principal drivers of bryophyte diversity, causing changes in their distribution ranges (He et al. 2016), it is also worth considering the concurrent effect of tree species identity in future research.

The identity of the tree species also had a pronounced influence on bryophyte species composition. We identified as many as 15 pairs of tree species that differed significantly in bryophyte species composition. This indicate that the process occurring in the structure of bryophyte communities, including the replacement of certain species by others, may be of great importance especially when species richness itself would be a poor indicator of the ground bryophyte conversion induced by changes in stand composition. The abundance of bryophytes associated mostly with coniferous trees (cf Fig. 2) may also experience a decline as a consequence of regression of certain coniferous species from forests in the temperate zone. Consequently, even if a local diversity will not decrease significantly, strong changes in ground bryophyte composition will probably occur.

Two species of acrocarpous mosses considered as expansive were also recorded, i.e. Dicranum tauricum and Dicranoweisia cirrata. They were recorded only in a single plots of Pinus sylvestris and Pinus nigra. The fact that the species were not found in any other surrounding study plots indicates that they are at the beginning of their colonisation of this area and it can be assumed that they have settled the study area only recently. The spread of these species and the range of occupied habitats could increase with time after initial colonisation, depending on an invader's ability to establish in new communities (Söderström 1992). It is also surprising that both species, which almost always colonise the bark of trees, were not observed growing epiphytically there nor on the rest of the fallen branches or bark, but directly on the forest litter. The increase of abundance in Central-East Europe, such as in Poland, has only been reported in last two decades (Stebel and Plášek 2001; Stebel et al. 2012). Such expansive species are increasingly viewed as a significant component of global change and in many cases one of the major drivers of current biodiversity loss (Didham et al. 2007). Nevertheless, in the context of global climate changes, even highly dispersive organisms like expansive bryophytes could be not equipped to fully track the rates of ongoing changes in the course of the next decades (Zanatta et al. 2020).

\section{Implications for management}

Forest integrity is considered to be important conservation point that guarantees desirable characteristics such as natural biodiversity, stand structure and continuity (Frego 2007). Although its defining criteria are still under discussion, bryophytes are proposed as important components of forest integrity, because they play a vital role in soil development, nutrient biogeochemical cycling, and ecological succession and indicate changes associated with specific forest processes. Our results provide data that can be useful in reasonably promoted forest regeneration treatments aimed at biodiversity conservation both in degraded forests and after clear-cuts. The inclusion of certain species into the stand may have a beneficial effect on bryophyte communities. Firstly, by means of changing the microhabitat conditions, which could be more favourable for bryophyte species occurrence and/or provide a heterogeneity of habitat factors that would promote the appearance of more diverse assemblages. Secondly, we indicated that bryophyte communities regenerate much faster under certain tree species after clear-cutting. Some trees ensure higher bryophyte species richness and faster entry of species characteristic for a given plant community. Providing suitable conditions for bryophytes to colonise and establish in young forest stands after logging is a key factor 
for bryophyte diversity and species composition in mature forests. We showed that the preference for tree species forming plant communities inherent to the natural habitat in forestry is highly beneficial for the biodiversity of ground bryophytes. Consequently, we support the idea of maintaining the selection of Quercus robur and Pinus sylvestris for plantings in managed forests planted on habitats typical for mixed coniferous forests (Querco roboris-Pinetum), which constitute a potential natural vegetation in the area of 13.64\% of Poland (Matuszkiewicz 2008). This is also in agreement with the currently promoted forest management strategies aimed at diversification of tree species in order to increase and/or maintain a high level of understorey biodiversity.

\section{Conclusions}

The experimental forest founded after clearing, stump removal, and ploughing gave us an opportunity to trace the colonisation processes of ground bryophytes from nearby mixed coniferous forest communities over a period of 50 years. Due to the persistent close connection of the experimental plots with the neighbouring mature forests, it is now possible to compare formed bryophyte assemblages and to estimate the impact of 14 tree species on them. Our study showed that overstorey tree species had a great impact on bryophyte communities. Therefore, we can assume that changes in the dominant tree species in the stand may result in significant changes in ground bryophyte communities. The effect of tree species identity on bryophyte species composition seems to be even greater than on species richness. This indicate that the process occurring in the structure of bryophyte communities may be of great importance especially when species richness itself would be a poor indicator of the ground bryophyte conversion induced by changes in stand composition. Moreover, the related soil chemistry and other habitat parameters, including light conditions and the vascular plant layer, also proved to be of great importance to the richness and cover of bryophytes in the forest floor. Nevertheless, the effect of tree species and habitat parameters is a network of mutual connections which, only when interpreted jointly, can explain the changes taking place in bryophyte communities. Generally, we found significantly higher bryophyte species richness and cover in the plots representing coniferous trees. Soil $\mathrm{pH}$, concentration of macronutrients $(\mathrm{Ca}, \mathrm{K}$, and $\mathrm{Mg}$ ) in soils, vascular plant layer and light conditions, proved to be the key habitat factors influencing the occurrence of ground bryophytes, and the effects of these parameters are related to the tree species effect. We also indicated that the introduction of alien tree species, in particular Q. rubra, may have an adverse effect on bryophyte communities. Finally, we conclude that the selection of tree species (i.e. $Q$. robur and $P$. sylvestris) that form plant communities consistent with the natural habitat (Querco roboris-Pinetum) in forestry is highly beneficial for maintaining ground bryophyte biodiversity.

Supplementary Information The online version contains supplementary material available at https://doi.org/10.1007/ s11104-021-05074-w.

Acknowledgements We are grateful to the authorities of the Siemianice Experimental Forest, especially to Janusz Szpyt, Eng. D., of the Department of Silviculture, Poznań University of Life Science, for their permission to conduct the study. We are also grateful to Piotr Osyczka (Institute of Botany, Jagiellonian University) for helpful discussion and constructive comments. The research was funded by the National Science Centre, Poland [grant number 2017/27/N/NZ8/00999], and also received financial support, in part, from the Institute of Botany, Faculty of Biology, Jagiellonian University in Cracow [grant numbers K/ZDS/ 008054, N18/DBS/000002]. The work of V.P. is part of research projects of University of Ostrava No. SGS14/PřF/2021 and EU structural funding Operational Programme Research and Development for Innovation No. CZ.1.05/2.1.00/19.0388.

Authors' contributions Kaja Rola: Conceptualization, Methodology, Formal analysis, Investigation, Resources, Data Curation, Writing-Original Draft, Writing-Review \& Editing, Visualization, Supervision. Vítězslav Plášek: Conceptualization, Data Curation, Investigation, Resources, Writing-Review \& Editing. Katarzyna Rożek: Investigation, Resources, Writing-Review \& Editing, Funding acquisition. Szymon Zubek: Investigation, Resources, Writing-Review \& Editing.

Funding The research was funded by the National Science Centre, Poland [grant number 2017/27/N/NZ8/00999], and also received financial support, in part, from the Institute of Botany, Faculty of Biology, Jagiellonian University in Cracow [grant numbers K/ZDS/ 008054, N18/DBS/000002]. The work of V.P. is part of research projects of University of Ostrava No. SGS14/PřF/2021 and EU structural funding Operational Programme Research and Development for Innovation, project No. CZ.1.05/2.1.00/19.0388. 
Data availability The data generated or analysed during this study are included in this published article (and its supplementary information files). Additional data are available from the corresponding author on request.

\section{Code availability Not applicable}

\section{Declarations}

Conflicts of interest/Competing interests The authors have no conflicts of interest to declare that are relevant to the content of this article.

Open Access This article is licensed under a Creative Commons Attribution 4.0 International License, which permits use, sharing, adaptation, distribution and reproduction in any medium or format, as long as you give appropriate credit to the original author(s) and the source, provide a link to the Creative Commons licence, and indicate if changes were made. The images or other third party material in this article are included in the article's Creative Commons licence, unless indicated otherwise in a credit line to the material. If material is not included in the article's Creative Commons licence and your intended use is not permitted by statutory regulation or exceeds the permitted use, you will need to obtain permission directly from the copyright holder. To view a copy of this licence, visit http://creativecommons.org/licenses/by/4.0/.

\section{References}

Anderson MJ (2001) A new method for non-parametric multivariate analysis of variance. Austral Ecol 26:32-46

Anderson MJ, Gorley RN, Clarke KR (2016) "PERMANOVA+ for PRIMER: Guide to Software and Statistical Methods". PRIMER-E. Plymouth, UK

Arno T, De Keersmaeker L, Van Calster H, De Schrijver A, Vandekerkhove K, Verstraeten G, Verheyen K (2012) Diverging effects of two contrasting tree species on soil and herb layer development in a chronosequence of postagricultural forest. For Ecol Manag 278:90-100

Augusto L, Ranger J, Binkley D, Rothe A (2002) Impact of several common tree species of European temperate forests on soil fertility. Ann For Sci 59:233-253

Augusto L, Dupouey J, Ranger J (2003) Effects of tree species on understory vegetation and environmental conditions in temperate forests. Ann For Sci 60:823-831

Bartels SF, MacDonald SE, Johnso D, Caners RT, Spence JR (2018) Bryophyte abundance, diversity and composition after retention harvest in boreal mixedwood forest. J Appl Ecol 55:947-957

Bartemucci P, Messier C, Canham CD (2006) Overstory influences on light attenuation patterns and understory plant community diversity and composition in southern boreal forests of Quebec. Can J For Res 36:2065-2079

Bates JW (2008) Mineral nutrition and substratum ecology. In: Goffinet B, Shaw AJ (eds) Bryophyte Biology, 2nd edn. Cambridge University Press, Cambridge, pp 299-356

Bergamini A, Pauli D, Peintinger M, Schmid B (2001) Relationships between productivity, number of shoots and number of species in bryophytes and vascular plants. J Ecol 89:920-929

Bernhardt-Römermann M, Poschlod P, Hentschel J (2018) BryForTrait-A life-history trait database of forest bryophytes. J Veg Sci 29:798-800

Chmolowska D, Nobis M, Nowak A, Maslak M, Kojs P, Rutkowska J, Zubek S (2019) Rapid change in forms of inorganic nitrogen in soil and moderate weed invasion following translocation of wet meadows to reclaimed post-industrial land. Land Degrad Dev 30:964-978

Chmura D, Sierka E (2007) The invasibility of deciduous forest communities after disturbance: a case study of emopenCarex brizoidesemclose and emopenImpatiens parvifloraemclose invasion. For Ecol Manag 242:487-495

Chmura D (2013) Impact of alien tree species Quercus rubra L. on understory environment and flora: a study of the Silesian Upland (southern Poland). Pol J Ecol 61:431-442

Clarke KR (1993) Non-parametric multivariate analysis of changes in community structure. Aust J Ecol 18:117-143

Dickie IA, Bolstridge N, Cooper JA, Peltzer DA (2010) Coinvasion by Pinus and its mycorrhizal fungi. New Phytol 187:475-484

Didham RK, Tylianaki JM, Gemmell NJ, Rand TA, Ewers RM (2007) Interactive effects of habitat modification and species invasion on native species decline. Trends Ecol Evol 22:489-496

Dirnböck T, Grandin U, Bernhardt-Römermann M, Beudert B, Canullo R, Forsius M, Grobner MT, Holmerg M, Kleemda S, Lundin L, Mirtl M, Neumann M, Pompei E, Salemaa M, Starlinger F, Staszewski T, Uziębło AK (2014) Forest floor vegetation response to nitrogen deposition in Europe. Glob Change Biol 20:429-440

Dobrylovska D (2001) Litter decomposition of red oak, larch and lime tree and its effect on selected soil characteristics. J For Sci 47:477-485

Dyderski MK, Paź S, Frelich LE, Jagodziński AM (2018) How much does climate change threaten European forest tree species distributions? Glob Change Biol 24:1150-1163

Ellenberg H, Düll R, Wirth V, Werner W, Paulißen D (1991) Zeigerwerte von Pflanzen in Mitteleuropa (Scripta Geobotanica Vol. 18), 2nd ed. Verlag Erich Goltze KG, Göttingen

Ellison AM, Bank MS, Clinton BD, Colburn EA, Elliott K, Ford CR, Foster DR, Kloeppel BD, Knoepp JD, Lovett GM, Mohan J, Orwig DA, Rodenhouse NL, Sobczak WV, Stinson KA, Stone JK, Swan CM, Thompson J, Von Holle B, Webster JR (2005) Loss of foundation species: consequences for the structure and dynamics of forested ecosystems. Front Ecol Environ 3:479-486

Evans SA, Halpern CB, McKenzie D (2012) The contribution of forest structure and substrate to bryophyte diversity and abundance in mature coniferous forests of the Pacific Northwest. Bryologist 115:278-294

Ewald J (2009) Epigeic bryophytes do not improve bioindication by Ellenberg values in mountain forests. Basic Appl Ecol 10:420-426

Ferré C, Comolli R (2020) Effects of Quercus rubra L. on soil properties and humus forms in 50-year-old and 80-yearold forest stands of Lombardy plain. Ann For Sci 77:3 
Fojcik B, Wierzgoń M, Chmura D (2019) Response of bryophytes to disturbances in managed forests. A case study from a Polish forest. Cryptogam Bryol 40(10):105-118

Frego KA (2007) Bryophytes as potential indicators of forest integrity. For Ecol Manag 242:65-75

Fritz Ö, Niklasson M, Churski M (2009) Tree age is a key factor for the conservation of epiphytic lichens and bryophytes in beech forests. Appl Veg Sci 12:93-106

Gosselin M, Fourcin D, Dumas Y, Gosselin F, Korboulewsky N, Toïgo M, Vallet P (2017) Influence of forest tree species composition on bryophytic diversity in mixed and pure pine (Pinus sylvestris L.) and oak (Quercus petraea (Matt.) Liebl.) stands. For Ecol Manag 406:318-329

Hammer Ø, Harper DAT, Ryan PD (2001) PAST: Paleontological Statistics Software Package for Education and Data Analysis. Palaeontol Electron 4:1-9

He X, He KS, Hyvönen J (2016) Will bryophytes survive in a warming world? Perspect Plant Ecol Evol Syst 19:49-60

Hill MO, Bell N, Bruggeman-Nannenga M, Brugues M, Cano MJ, Enroth J, Flatberg KJ, Frahm JP, Gallego MT, Garilleti R, Guerra J, Hedenäs L, Holyoak DT, Hyrönen Ignator MS, Lara F, Mazimpaka V, Muňoz J, Söderström L (2006) An annotated checklist of the mosses of Europe and Macaronesia. J Bryol 28:198-267

Hill MO, Preston CD, Bosanquet SDS, Roy DB (2007) BRYOATT: Attributes of British and Irish Mosses, Liverworts and Hornworts. Centre for Ecology and Hydrology, Wallingford

Hobbie SE, Reich PB, Oleksyn J, Ogdahl M, Zytkowiak R, Hale C, Karolewski P (2006) Tree species effects on decomposition and forest floor dynamics in a common garden. Ecol 87:2288-2297

Humphrey JW, Davey S, Peace AJ, Ferris R, Harding K (2002) Lichens and bryophyte communities of planted and seminatural forests in Britain: the influence of site type, stand structure and deadwood. Biol Conserv 107:165-180

Ingerpuu L, Liira J, Pärtel M (2005) Vascular plants facilitated bryophytes in a grassland experiment. Plant Ecol 180:69-75

Jagodziński AM, Wierzcholska S, Dyderski MK, Horodecki P, Rusińska A, Gdula AK, Kasprowicz M (2018) Tree species effects on bryophyte guilds on a reclaimed post-mining site. Ecol Eng 110:117-127

Jansová I, Soldan Z (2006) The habitat factors that affect the composition of bryophyte and lichen communities on fallen logs. Preslia 78:67-86

Jiang T, Yang X, Zhong Y, Tang Q, Liu Y, Su Z (2018) Species composition and diversity of ground bryophytes across a forest edge-to-interior gradient. Sci Rep 8(1): 1868

Király I, Ódor P (2010) The effect of stand structure and tree species composition on epiphytic bryophytes in mixed deciduous-coniferous forests of Western Hungary. Biol Conserv 143:2063-2069

Kottek M, Grieser J, Beck C, Rudolf B, Rubel F (2006) WorldMap of the Köppen-Geiger climate classification updated. Meteorol Z 15(3):259-263

Kriebitzsch WU, Bültmann H, von Oheimb G, Schmidt M, Thiel H, Ewald J (2013) Forest-specific diversity of vascular plants, bryophytes, and lichens. In: Kraus D, Krumm F (eds) Integrative Approaches as an Opportunity for the
Conservation of Forest Biodiversity. European Forest Institute, Joensuu, pp 58-169

Kubiak D, Osyczka P (2017) Specific vicariance of two primeval lowland forest lichen indicators. Environ Manag 59:966-981

Lepš J, Šmilauer P (2003) Multivariate Analysis of Ecological Data Using CANOCO. Cambridge University Press, Cambridge

Löbel S, Dengler J, Hobohm C (2006) Species richness of vascular plants, bryophytes and lichens in dry grasslands: The effects of environment, landscape structure and competition. Folia Geobot 41:377-393

Longton RE (1992) The role of bryophytes and lichens in terrestrial vegetation. In: Bates JW, Farmer AM (eds) Bryophytes and lichens in a changing environment. Clarendon Press, Oxford, pp 32-76

Matuszkiewicz JM (2008) Potential natural vegetation of Poland (Potencjalna roślinność naturalna Polski), IGiPZ PAN, Warszawa

Mäkipää R, Heikkinen J, Mikkola K, Reinikainen A, Salemaa M (2000) Changes in Abundance of Some Forest Floor Mosses. In: Mälkönen E (eds) Forest Condition in a Changing Environment. Forestry Sciences. Springer, Dordrecht, vol 65

Márialigeti S, Tinya F, Bidló A, Ódor P (2016) Environmental drivers of the composition and diversity of the herb layer in mixed temperate forests in Hungary. Plant Ecol 217:549-563

Márialigeti S, Németh B, Tinya F, Ódor P (2009) The effects of stand structure on ground-floor bryophyte assemblages in temperate mixed forests. Biodivers Conserv 18:2223-2241

Mills SE, MacDonald SE (2004) Predictors of moss and liverwort species diversity of microsites.in conifer-dominated boreal forest. J Veg Sci 15:189-198

Mills SE, MacDonald SE (2005) Factors influencing bryophyte assemblage at different scales in the Western Canadian boreal forest. Bryologist 108:86-100

Moora M, Daniell T, Kalle H, Liira J, Pussa K, Roosaluste E, Opik M, Wheatley R, Zobel M (2007) Spatial pattern and species richness of boreonemoral forest understorey and its determinants - a comparison of differently managed forests. For Ecol Manag 250:64-70

Müller J, Boch S, Prati D, Socher SA, Pommer U, Hessenmöller D, Schall P, Schulze ED, Fischer M (2019) Effects of forest management on bryophyte species richness in Central European forests. For Ecol Manag 432:850-859

Nordén U (1994) The influence of broad-leaved tree species on $\mathrm{pH}$ and organic matter content of forest topsoils in Scania, South Sweden. Scand J For Res 9:1-8

Oechel WC, Van Cleve K (1986) The role of bryophytes in nutrient cycling in the taiga. In: Van Cleve K, Chapin FS, Dryness CT, Viereck LA, Flanagan PW (eds) Forest ecosystems in the Alaskan taiga. A synthesis of structure and function. Springer, Berlin, Heidelberg, New York

Olsen SR, Sommers LE (1982) Phosphorus. In: Page AL, Miller RH, Keeney DR (eds) Methods of Soil analysis. Part 2. Chemical and microbiological properties. 
Agronomy Monograph. Number 9. Second edition. ASA-SSSA, Madison, Wisconsin, USA

Proctor MCF (2008) Physiological ecology. In: Goffinet B, Shaw AJ (eds) Bryophyte biology, 2nd edn. Cambridge University Press, Cambridge, pp 237-268

Reich PB, Oleksyn J, Modrzyński J, Mroziński P, Hobbie SE, Eissenstat DM, Chorover J, Chadwick OA, Hale CM, Tjoelker MG (2005) Liking litter calcium, earthworms and soil properties: a common garden test with 14 tree species. Ecol Lett 8:811-818

Rożek K, Rola K, Błaszkowski J, Leski T, Zubek S (2020) How do monocultures of fourteen forest tree species affect arbuscular mycorrhizal fungi abundance and species richness and composition in soil? For Ecol Manag 465:118091

Rutkowski L (2014) Klucz do oznaczania roślin naczyniowych Polski niżowej. Wydawnictwo Naukowe PWN, Warszawa

Rydin H (2008) Population and community ecology of bryophytes. In: Goffinet B, Shaw AJ (eds) Bryophyte Biology, 2nd edn. Cambridge University Press, Cambridge, pp 393-444

Schueler S, Falk W, Koskela J, Lefèvre F, Bozzano M, Hubert J, Kraigher H, Longauer R, Olrik DC (2014) Vulnerability of dynamic genetic conservation units of forest trees in Europe to climate change. Glob Change Biol 20:1498-1511

Söderström L (1992) Invasions and range expansions and contractions of bryophytes. In: Bates JW, Farmer AM (eds) Bryophytes and lichens in a changing environment. Clarendon, Oxford, pp 131-158

Startsev N, Lieffers VJ, Landhausser SM (2008) Effects of leaf litter on the growth of boreal feather mosses: implication for forest floor development. J Veg Sci 19:253-260

Stebel A, Plášek V (2001) Dicranoweisia cirrata and Orthodicranum tauricum (Musci) in the Polish and Czech part of Upper Silesia - Distribution and ecology. Natura Silesiae Superioris Katowice 5:21-31

Stebel A, Virchenko VM, Plášek V, Ochyra R, BednarekOchyra H (2012) Range extension of Orthodicranum tauricum (Bryophyta, Dicranaceae) in Central-East Europe. Pol Bot J 57:119-128

Stefanowicz AM, Majewska ML, Stanek M, Nobis M, Zubek S (2018) Differential influence of four invasive plant species on soil physicochemical properties in a pot experiment. $\mathbf{J}$ Soils Sediments 18:1409-1423

Stefanowicz AM, Rożek K, Stanek M, Rola K, Zubek S (2021) Moderate effects of tree species identity on soil microbial communities and soil chemical properties in a common garden experiment. For Ecol Manag 482:118799

Stefanowicz AM, Stanek M, Nobis M, Zubek S (2017) Few effects of invasive plants Reynoutria japonica, Rudbeckia laciniata and Solidago gigantea on soil physical and chemical properties. Sci Total Environ 574:938-946

Szymański S (1982) Growth of some forest tree species in the first 10 years on fairly poor mixed conifer sites. Sylwan 126:11-29 ter Braak CJF, Smilauer P (2002) CANOCO reference manual and canodraw for windows user's guide: software for canonical community ordination (version 4.5). Microcomputer Power, Ithaca, New York

Thomas SC, Halpern CB, Falk DA, Liguori DA, Austin KA (1999) Plant diversity in managed forests: understory responses to thinning and fertilization. Ecol Appl 9:864-879

Tilk M, Ots K, Tullus T (2018) Effect of environmental factors on the composition of terrestrial bryophyte and lichen species in Scots pine forests on fixed sand dunes. For Syst 27:e015

Tinya F, Márialigeti S, Király I, Németh B, Ódor P (2009) The effect of light conditions on herbs, bryophytes and seedlings of temperate mixed forests in Orség. Western Hungary Plant Ecol 204(1):69-81

Turetsky MR (2003) The role of bryophytes in carbon and nitrogen cycling. Bryologist 106:395-409

Turkington R, Elizabeth J, Krebs C, Dale MRT, Nams VO, Boonstra R, Boutin S, Martin K, Sinclair ARE, Smithn JNM (1998) The effects of NPK fertilization for nine years on boreal forest vegetation in northwestern Canada. J Veg Sci 9:333-346

Vellak K, Ingerpuu N (2005) Management effects on bryophytes in Estonian forests. Biodivers Conserv 14:3255-3263

Virtanen R, Johnston AE, Crawley MJ, Edwards GR (2000) Bryophyte biomass and species richness on the Park Grass Experiment, Rothamsted, UK. Plant Ecol 151:129-141

von Arx G, Dobbertin M, Rebetez M (2012) Spatio-temporal effects of forest canopy on understory microclimate in a long-term experiment in Switzerland. Agric For Meteorol 166-167:144-155

Weibull H, Rydin H (2005) Bryophyte species richness on boulders: relationship to area, habitat diversity and canopy tree species. Biol Conserv 122:71-79

Woziwoda B, Kopeć D, Witkowski J (2014) The negative impact of intentionally introduced Quercus rubra L. on a forest community. Acta Soc Bot Pol 83(1):39-49

Woziwoda B, Staniaszek-Kik M, Stefańska-Krzaczek E (2017) Assemblages of native bryophytes in secondary forests with introduced Quercus rubra. Nord J Bot 35:111-120

Yan XL, Bao WK, Pang XY, Zhang N, Chen J (2013) Regeneration strategies influence ground bryophyte composition and diversity after forest clearcutting. Ann For Sci 70:845-861

Zanatta F, Engler R, Collart F, Broennimann O, Mateo RG, Papp B, Muñoz J, Baurain D, Guisan A, Vanderpoorten A (2020) Bryophytes are predicted to lag behind future climate change despite their high dispersal capacities. Nat Commun 11:5601

Publisher's note Springer Nature remains neutral with regard to jurisdictional claims in published maps and institutional affiliations. 